enough worse material. Such a definition, if adopted, would be "calculated to facilitate the work of the unfortunate public analysts who may be called upon to express an opinion as to the genuineness of a sample of brandy,' and the question, what is brandy? analytically speaking, would no longer " await solution." Recent analyses to which you refer have at any rate reduced a large section of the brandy trade to the confession that much of the stuff they sold never had its origin in the grape at all. The public house trade now posts notices in the bars that it cannot guarantee the brandy sold to be genuine grape spirit.

The attitude of the French committee is not difficult to understand, and there can be no objection to it so long as the trade, in the interests of which it has undertaken the inquiry, determines on issuing an honest label setting forth that either the spirit is a pot still spirit from grape wine or it is not.

Bromley, Kent, November 8.

The Origin of Life.

Although there are good reasons for believing that the life of our world is the product of its own physical conditions, and distinct from the life of other members of the solar system, it is hardly probable that living substance can be produced otherwise than by the same conditions that produced it in the past, and one of these conditions is a vast period of time.

We are not acquainted with any life apart from "cells." But the cell is a very complex organism, and between inorganic substance and the cell there may have been as long a course of evolution as between the cell and the highest existing animal or vegetable. Probably most biologists nowadays regard life not as an entity (e.g. not as a "vital force "), but rather as a coordination of many physical processes which have become more numerous and better coordinated in the course of evolution. It is not to be supposed that the total functions of life would be developed in not-living substances under the restricted conditions of human experiment; nevertheless, some of the individual functions might be brought into action, at least in a primitive form.

One of these functions, which I believe to be the most fundamental, is the deoxidation of a compound containing the elements $\mathrm{N}, \mathrm{O}, \mathrm{C}, \mathrm{H}, \& \mathrm{c}$, by the action of light, moderate heat, or slight electrical disturbance. This is the foundation of biosynthesis-a small beginning which in the course of ages develops mechanisms so perfect as the photosynthesis in chlorophyll-bearing cells. We ought by research to discover the conditions on which such deoxidation depends, and imitate it in our laboratories; we might even apply it to important economic purposes.

This deoxidation is probably a perfectly natural process, as natural as the opposite process of oxidation, only it must not be sought in the behaviour of mere oxides, as $\mathrm{CO}_{2}$, but rather in that of compounds containing $\mathrm{N}, \mathrm{O}, \mathrm{C}, \mathrm{H}$, \&., as above suggested. In fact, it may be expected to be nearly a reversal of the process of vital oxidation, which has been more successfully investigated. Vital oxidation seems to take place in two stages, as follows:-(I) the $\mathrm{O}$ is taken into combination with the $\mathrm{N}$ in a complex molecule, (2) it is transferred from the $N$ to a more oxidisable element. Whether complete linking occurs between $\mathrm{O}$ and $\mathrm{N}$, as $\mathrm{O}=\mathrm{N} \equiv$, we cannot say; but the linkings $\equiv \mathrm{C}-\mathrm{O}-\mathrm{N} \equiv$ and $\mathrm{H}-\mathrm{O}-\mathrm{N} \equiv$ are probable. The oxygen-carrying function of $\mathrm{N}$ seems to be assisted in many (if not all) cases by $\mathrm{Fe}$.

First attempts at life may be occurring continually around us, but if any synthetic substances be formed they are sure to be seized and assimilated by the already developed organisms.

Cambridge, November 12 .

\section{Change in the Colour of Moss Agates.}

Is connection with Mr. Whitton's inquiry (NATURE, November 10, p. $3 \mathrm{I}$ ), the following note may be of interest.

On the top of the West Cliff at Bournemouth the road is laid with material which includes a number of flint pebbles. These are, as a rule, rounded or subangular, and of a yellow or whitish-yellow colour as regards their general surface. But where exposed to the air the colour has

No. I829. VOL. 7 I] changed to deep blue, violet, or purple, and so much so that in places the whole surface of the road has a marked blue shimmer. Or perhaps it should rather be said that this was the case last autumn; I have not seen it since.

As will be seen from the enclosed specimen, the contrast between the imbedded and the exposed portion of the pebbles is very striking.

Without giving any special study to the matter, I was inclined at the time to attribute the phenomenon either to a further oxidation and hydration of the iron which is, no doubt, present in the flints, or, possibly, to a molecular rearrangement of the silica. At some points the blue colour passes almost into black; this suggests that it may indicate a transition stage between yellow and black flints.

Possibly some mineralogist has examined the matter more thoroughly. C. Simmonds.

Northcroft, Deronda Road, Herne Hill, November I4.

Chemical Analysis for Beginners

IN a review on this subject (this vol., p. 5) "J. B. C." directs attention once again to the unsuitability of an extended study of analysis for a beginner. His opinions not only claim respect, but must be largely shared by all teachers of chemistry.

There is, however, a side to the question which somehow seems rather to be overlooked. The average elementary student will work patiently for hours over qualitative analysis, well taught, badly taught, or not taught at allhe is interested, and though none too willing to use brains as well as tables, he is ready under guidance to do his best. But in any logical system of elementary quantitative and preparation work calculated to build up a firm foundation in the principles of chemistry he appears to take no natural interest, when it comes to actual work. Possibly "J. B. C." will not agree that this is so; and it may be right that the student should be compelled (if it can be done) to think logically from the first. But it seems not unimportant to interest him in practice as well as " on paper."

I do not refer to the embryo professional chemist who soon gets through the introductory work and is nearly always interested, but to that enormous crowd of text-book consumers who spend, possibly, three hours per week in the chemical laboratory as part of their scheme of study. Does not the marked change of attitude in such students when oualitative analysis is touched upon indicate that there is still room for fundamental improvement in the method of presenting first steps in practical chemistry?

F. SOUTHERden.

Royal Albert Memorial College, Exeter.

\section{Misuse of Words and Phrases.}

IN Mr. Basset's book, to which he refers in NATURE of November Io (p. 30 ), he speaks of the advantage of having " a concise and pointed mode of expression, which saves a great deal of circumlocution and verbosity." $\mathrm{He}$ thinks that this object is best gained by coining a new word from the Greek, for instance, autotomic, whereas I hold that the same object is better gained by adopting a word of English derivation, self-cutting. Mr. Basset now says that he considers this word "inelegant," and, in the absence of any standard of elegance, I can only reply that this is a matter of individual taste. Perhaps it would be better still to call a curve that has double points a " nodal curve," and one that has none a " nodeless curve." The word binodal is already in use.

As regards the phrase "non-singular cubic," it is clearly inaccurate if, with Plücker, we speak of "singular lines" as well as "singular points," and include all these under the term singularities; but I rather think that in English books the term singularity was formerly not applied to double tangents, or even to points of infection.

November 14.

\section{Reason in Dogs.}

Apropos of "thinking cats," perhaps the following story of a practical joke played by a dog will interest your readers.

A friend of mine, Mr. W., owns a Manchester terrier of which he is very fond, and for that reason receives rather more than doggy attention. The dog passes most of his time in the library, where a basket and rug are provided for him, but he prefers, when it is possible, to take possession 